\title{
Was the 1982 Velocity Decline Unusual?
}

\author{
JOHN A. TATOM
}

T

HE nation's GNP growth in 1982 was so weak relative to the pace of monetary expansion that the velocity of money - the ratio of GNP to M1 - fell significantly. This decline contrasts sharply with the steadily rising trend in velocity over the past 35 years.

The Council of Economic Advisers (CEA) refers to 1982 velocity behavior as "historically atypical" and "not fully understood." In explaining the large velocity "shift," the CEA attributes a major role to changes in asset demands of individuals and businesses, arising from new financial opportunities or changes in asset preferences. The CEA phrases the importance of unusual shifts in velocity growth succinctly:

The presumption, on the basis of past experience, is that most velocity changes are temporary. Thus, increasing the rate of monetary growth in response to temporary declines in velocity runs the risk of providing excessive liquidity and increasing inflation, while a failure to recognize a continuing shift in liquidity prefer ence or velocity runs the risk of providing inadequate liquidity and reducing real GNP.

Had velocity growth not shifted last year, nominal GNP growth would have been substantially higher, and the recession presumably would have not been as lengthy or as severe.

Some observers, interpreting this development as the breakdown of monetarist theory, have suggested that "If velocity has become impossible to predict, it could be 20 years before monetarism becomes the linchpin of policy again." ${ }^{2}$ Before concluding that the

\footnotetext{
${ }^{1}$ Economic Report of the President (Government Printing Office, 1983), pp. 21-22

${ }^{2}$ See "The Failure of Monetarism," Busines.s Week, April 4, 1983, pp. 64-67. In the same article, Robert J. Gordon remarks that "monetarism has been decimated by the collapse of velocity in 1982."
}

link between monetary growth and spending has been broken or addressing the implications of such a breakdown for monetary policy, it is useful to place last year's velocity developments in historical perspective and to examine the extent of any deviation in the historical relationship between velocity and the factors that influence it.

\section{THE RECENT BEHAVOR OR VEROCLTIN MISTORICA TERSPECTIVE}

On an annual basis, the velocity of $\mathrm{M} 1$ grew steadily from 1959 to 1981 , averaging a 3.2 percent rate of increase. In 1982, M1 velocity fell at a 2.3 percent rate. Since the standard deviation for velocity growth from $1959-81$ was only 1.20 percent, the recent decline, as the CEA has indicated, appears substantial. Indeed, any decline would appear unusual based on the record of systematic increases in velocity since 1959.

Declines in velocity are not unprecedented, however. For example, on an annual basis, M1 velocity fell at a 1.5 percent rate from 1953 to $1954 .{ }^{3}$ Moreover, there have been years in the postwar period when velocity growth was virtually nil, such as $1952(0.2$ percent) and 1958 (0.1 percent). ${ }^{4}$

\footnotetext{
${ }^{3}$ The current measure of $\mathrm{M} 1$ begins in 1959 . The old measure used before 1980 is used here for the period 1947 to 1959 . In 1959 , the two measures were nearly identical so that an historical series is obtained by splicing the two series.

${ }^{4}$ L. R. Klein and R. F. Kosobud, "Some Econometrics of Growth: Great Ratios in Economies," The Quarterly Joumal of Economics (May 1961), pp. 173-98, argue that, adjusted for its trend rate of growth, velocity is one of the "great" ratios that might be viewed as a fundamental parameter for economic theory. They reach this conclusion, notwithstanding their evidence indicating periodic sharp velocity declines relative to trend.
} 
Chort

Velocity (GNP/MI)

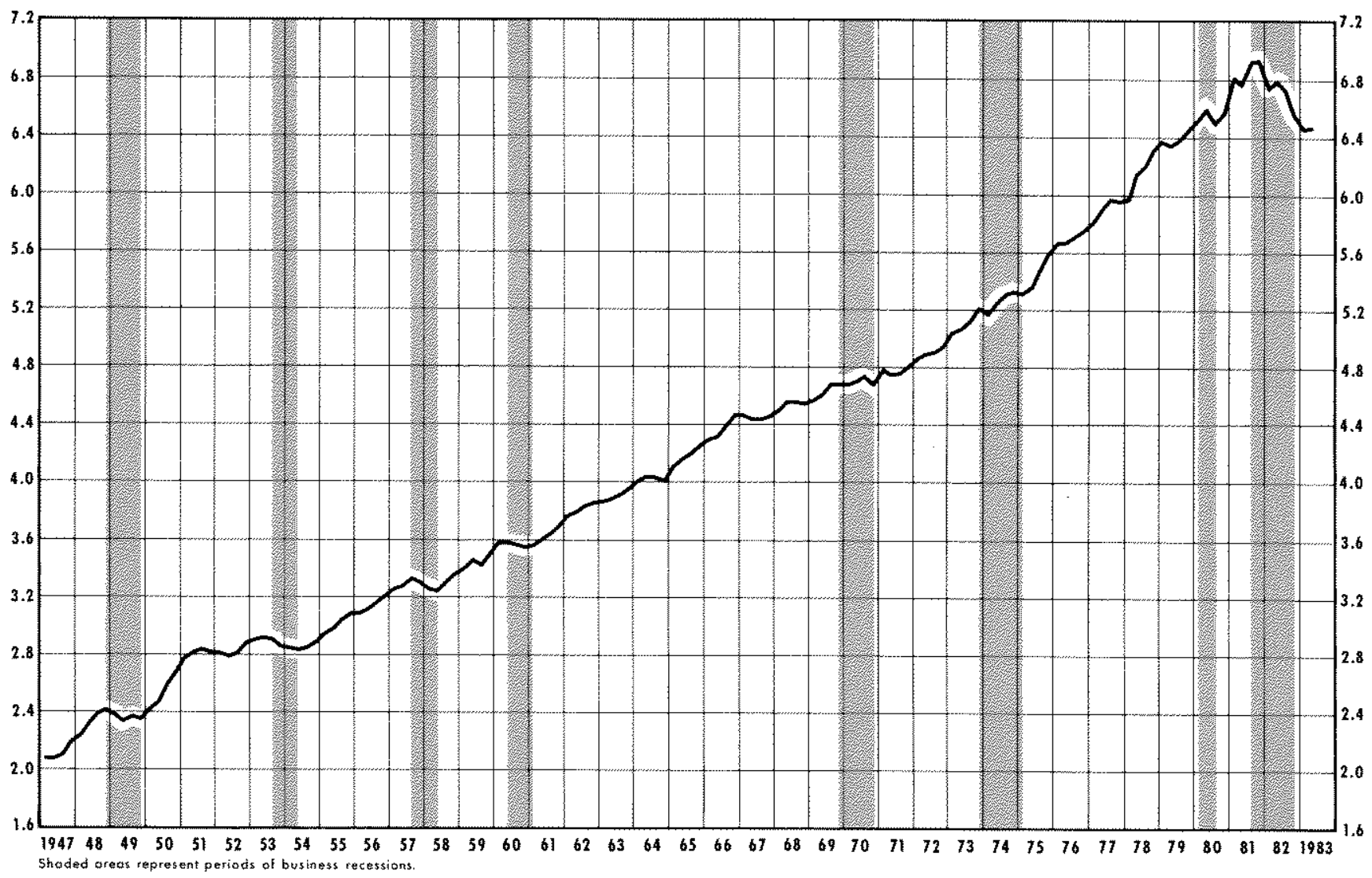

\section{The Ouarterly Record}

Additional insight into the 1982 velocity decline can be obtained using quarterly data. Velocity fell at an 11.2 percent annual rate in the first quarter of 1982 , rose at a 3.3 percent rate in the second quarter, fell at a 3.4 percent rate in the third quarter, then fell at a 9.9 percent rate in the last quarter of 1982. Chart 1 shows quarterly levels of velocity since 1947 ; periods of recession are shaded. Note that there are numerous quarters in which velocity fell, especially during recessions.

From the first quarter of 1947 to the third quarter of 1981, velocity declined in 32 of the 138 quarters, or about one-fourth of the time. Moreover, velocity typically fell in periods of economic decline. There are 25 quarters that span the peak-to-trough periods; velocity declined in 64 percent of them. Nonetheless, the mag; nitude of the velocity declines in the first and fourth quarters of 1982 far exceed the largest one-quarter decreases in velocity of about 6 percent observed in I/1948, IV/1948, IV/1953 and I/1958. One would have to look back to 1945 or earlier recessions to find more rapid decreases in velocity.

Table I shows velocity"s growth rate from peak to trough in eight postwar recessions. While a decline in velocity in such periods is not unusual, the size of the peak-to-trough decline in the recent recession is the largest recorded. The velocity decline was fairly small in the four previous recessions. Indeed, in the 1970 recession, velocity was flat, and in the 1973-75 recession it rose. Yet, except for the $1973-75$ recession, when the unemployment rate rose 3.5 percentage points from peak to trough, the four previous recessions were not as severe as the recent experience when unemployment rose 3.3 percentage points from peak to trough. ${ }^{5}$ The recent experience compares more

"The data in table 1 suggest that velocity movements in the 1973-75 recession, when velocity actually increased, were more anomalous than recent velocity movements. The $1973-75$ change is consistent with a one-time downshift in the demand for money occurring during that recession. See R. W. Hater and Scott E. Fein "The Shift in Money Demand: What Really Happened?" this Review (February 1982), pp. 11-16. 
closely to that in the first three postwar recessions, when the unemployment rate rose about 3.2 percentage points from peak to trough. ${ }^{6}$

\section{ENPLANATONS OF DECENT VELOCIT MOVEMENTS}

The recent behavior of velocity is broadly consistent with the velocity declines that occurred in most previous recessions. Nonetheless, analysts have advanced a variety of hypotheses to account for the 1982 velocity experience. Two of these explanations are conventional: they are that (1) declining inflation, or (2) declining interest rates, have reduced the cost of holding money and, consequently, the demand for money relative to goods and services has increased. ${ }^{7}$

A second group of hypotheses includes those that usually are not incorporated in conventional analyses. Principal among these is that recent financial innovations have lowered the cost of holding money, thereby increasing its demand and reducing velocity. Another hypothesis in this vein is that international asset preferences have changed so that foreigners" demand for the U.S. money stock is greater. According to this

\footnotetext{
${ }^{6}$ Declining velocity in recessions is not a postwar phenomenon Using Fobert Gordon's estimates of quarterly GNP and Milton Friedman and Anna Schwart $z$ data on M1, a measure of M1 velocity can be constructed since mid-1914. In the seven recessions from 1919-45, velocity fell it all and, with one exception, at a faster pace than in the 1981-82 recession. The periods are (growth rates in parentheses): III/1918-1/1919 (-28.8 percent), $1 / 1920$ III/1921 (-6.6 pereent), I//1923-III/1924 (-6.7 percent), III 1926-IV/1927 (-2.2 percent), II/1929-I/1933 (-12.8 percent), IV/1937-II/1938 (-5.8 percent), and I/1945-IV/1945 (-22.5 percent). See Robert J. Gordon, "Price Inertia and Policy Ineffectiveness in the United States, 1890-1980," Journal of Political Economy (December 1982), pp. 1087 117; and Milton Friedman and Anna Jacobson Schwartz, A Monetary Histary of the United States, 1867-1960 (Princeton University Press, 1963).

"See Bluford H. Putnam, "This Money Bulge Isr't Inflationary," Wall Street Journal, April 27, 1983, for a discussion of these explanations and others. Also, see Jom P. Judd, "The hecent Decline in Velocity: Instability in Money Demand or Inflation?" Federal Reserve Bank of San Francisco Econonic Review (Spring 1983, forthcoming. Judd claims that declining interest rates explain the pattern of money growth since the end of 1981 and that the demand for money contained in the San Francisco money market model was stable. Velocity fell because of this predictable strength in money demand. fudd does not argue that the sensitivity of money denand to changes in interest rates and inflation has changed. An example of the latter argument is contaned in Flint Brayton, Terry Farr and Pichard Porter, "Alternative Money Demand Specifications and Recent Growth in MI" (Board of Covernors of the Federal Reserve System, May 23 , 1983; processed).
}

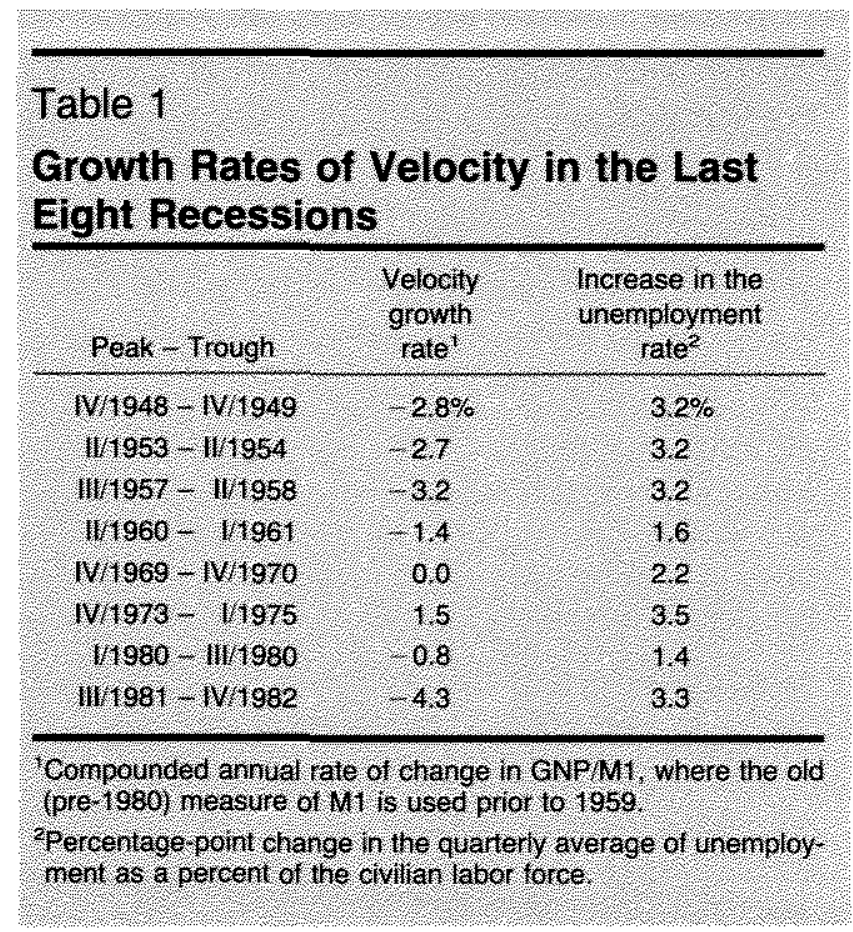

view, the international strength of the dollar accounts for the decline in velocity. ${ }^{8}$ All four explanations suffer from a lack of historical perspective that blunts their intuitive appeal.

\section{Declining Inflation}

Inflation has declined steadily since the first quarter of 1981, but velocity declines did not become a source of concern until a year later. As measured by the rate of increase in the GNP deflator, inflation peaked at 10.4 percent in the year ending in the first quarter of 1981. This rate declined to 7.1 percent over the following year, then to 4.7 percent in the year ending in the first quarter of 1983. The decline in velocity is concentrated heavily in only two quarters of 1982 , long after the decline in inflation began. Moreover, in the first three quarters of 1981, when the inflation was slowing sharp$\mathrm{ly}$, velocity rose at a 7.1 percent rate. Of course, it is conceivable that changes in expected inflation lagged far behind actual inflation developments, but lacking evidence of such a delayed and discontinuous adjustment process, such a notion can be disregarded.

\footnotetext{
"Putnam, "This Money Bulge," provides this explanation along with the declining inflation and financial imovation explanation. Also, see Vincent Salvo, "Is U.S. Money Growth A Foreign Affair?" International Finance, (Chase Manhattan Bank, April 25, 1983), pp. $1,7,8$.
} 


\section{Deching noterest Rates}

Explanations that focus on declining interest rates also do not match up well with the recent pattern of velocity declines. In the first quarter of 1982, corporate Aaa bond yields averaged 15.01 percent and had risen from 14.62 percent one quarter earlier or 14.92 percent two quarters earlier. During the remaining quarters of 1982, the bond yield declined to 14.51 percent, 13.75 percent and 11.88 percent. ${ }^{9}$ The pattern in the second half of 1982 is consistent with a decline in velocity. What remains unexplained, however, is the largest decline in velocity, which occurred in the first quarter.

\section{Thmonal Mnovertons}

Financial innovations are a widely discussed ex* planation of velocity shifts. This argument is by far the most puzzling, because there were no major innovations over the period in which velocity behavior appeared aberrant to most observers. Analysts generally refer to the introduction of super-NOW accounts or money market deposit accounts in connection with this hypothesis. Unfortunately, the former were not allowed until January 1983 and the latter were authorized in mid-December 1982 , three weeks before the end of the period of declining velocity discussed above. ${ }^{10}$

\section{Foreign Demand for the Dollar}

The international currency preferences explanation also does not match the recent velocity pattern. The

\footnotetext{
The use of short-term rates does not alter the disparate pattern. In the first quarter of $1982,3-$ month Treasury bill vields averaged 12.81 percent, higher than the 11.75 percent yield a quarter earlier, although somewhat below the 15.05 percent average vield two quarters earlier. This rate also declined over the subsequent three quarters.

${ }^{10}$ The only example of a major financial innovation in recent years that fits the hypothesis is the introduction of nationwide NOW accounts in January 1981. There was a sharp surge in the share of total checkable deposits held as NOW balances or other checkable deposits from January to April. Earlier analyses have failed to reveal any unusual velocity developments in 1981 due to this shift. See John A. Tatom, "Recent Financial Innovations: Have They Distorted the Meaning of Ml?" this Review (April 1982), pp. 23-35; Scott E. Hein, "Short-Run Money Growth Volatility; Evidence of Misbehaving Money Demand?" this Review (June/fuly 1982), pp. 27-36; Bryon Higgins and John Faust, "NOWs and Super-NOWs: Implications for Defining and Measuring Money," Federal Reserve Bank of Kansas City Economic Review (January 1983), pp. 3-18. On the absence of effects from the late 1982 and early 1983 innovations, see John A. Tatom, "Money Market Deposit Accounts, Super-NOWs and Monetary Policy," this Review (March 1983), pp. 5-16.
}

effective exchange rate has been rising steadily since the third quarter of 1980 , except for a decline in the fourth quarter of 1981 . The rates of increase in the exchange value of the dollar from III/1980 to III/1981 and from IV/1981 to IV/1982 are 28.8 percent and 16 percent, respectively. In the first period, velocity rose 5.6 percent despite the strong appreciation of the dollar. Only in the latter period, when the rate of appreciation slowed, did velocity growth slow.

An earlier example further illustrates the difficulty with this explanation. In the second quarter of 1981 , just before the recent recession, the exchange value of the dollar was virtually the same as in the third quarter of 1977. Over the four-year period, the exchange rate first fell rapidly (12 percent rate from III/1977 to IV/1978), then declined more slowly (1.6 percent rate from IV/1978 to III/1980), and finally surged upward (28.5 percent rate from III/1980 to II/1981). Over the same periods, velocity grew at $4.5,1.6$, and 5.6 percent rates, respectively. Thus, velocity growth was strongest during the period of rapid appreciation. Moreover, it was only slightly slower - and well above trend growth - during the period of rapid decline in the value of the dollar.

The conceptual difficulty with this explanation is that the movements in the exchange value of the dollar reflect inflation and monetary growth developments. At least for the United States, the major provider of the world money supply, these factors are included in conventional analyses of GNP growth and velocity. It is not likely that the exchange rate could exert a major impact of its own. ${ }^{11}$

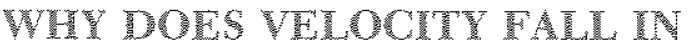 PCESSTONS?}

\section{Doclining Peal Income}

The principal reason that velocity declines in a recession is because of a temporary decline in real income. Velocity can be viewed as real income $(x)$ per

\footnotetext{
${ }^{11}$ The currency preferences argument also appears to confuse money and other fnancial assets. While the foreign demand for U.S. financial assets has risen dramatically, especially in 1980 and 1981, foreign ownership of money has not. Estimates based on individual, partnership and corporate deposits show essentially no change in the less than 2.5 percent of gross demand deposits due to foreign holders for December data from 1978 through 1982. Similarly, bank demand liabilities to foreigners, including all foreign banks or excluding foreign financial institutions, have shown no tendency to increase since 1979. Federal Reserve Bulletin (May 1983), p. A25 and p. A59.
} 
unit of real money balances (m). An income elasticity of demand for money less than one will yield procyclical velocity; for example, a 1 percent decline in real income will induce a smaller reduction in the demand for real money balances. As a result, velocity, $\mathrm{x} / \mathrm{m}$, will fall during a recession, other things held constant. ${ }^{12}$

\section{Lagged Adiusment of GNP bo Monerary Gown}

Velocity also typically falls in recessions due to the link between nominal GNP growth and money growth. The growth rate of nominal GNP is determined primarily by the growth rate of the money supply. There are lags, however, in the response of nominal GNP to changes in money growth. When money growth slows, GNP growth initially slows by less; thus, velocity growth rises. Within a few quarters, however, the effect of the slowing in money growth is reflected in further reductions in GNP growth so that, while GNP growth continues to slow and money growth does not, velocity growth falls.

Furthermore, the monetary theory of the business cycle indicates that, after some time (about two quarters), a substantial decline in the money growth will cause a recession. The periods of falling velocity growth associated with a slowing in money growth coincide with the period of recession induced by a slowing in money. ${ }^{13}$

The pattern of money growth over the last two years bears out this type of movement. Table 2 shows the

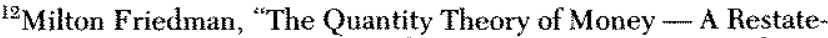
ment," in Milton Friedman, ed., Studies in the Quantity Theory of Money (University of Chicago Press, 1956), pp. 18-19, explains that the demand for money, in principle, depends on "expected income" or "permanent income." In recessions, measured income or GNP declines relative to permanent income. As a result, money holdings rise relative to measured income or $\mathrm{GNP}$, but not relative to permanent income. Such a movement in money holdings relative to spending also is expected based on a "precautionary motive" for holding money. As "The Failure of Monetarism" notes, "In a weak economy, fear of losing one ${ }^{x}$ job is a strong incentive for keeping a larger amount of money in a checking account in order to get at it quickly" (p. 64).

${ }^{83}$ The theory that velocity declines relative to trend during a reces sion because of the same slowing in money growth that causes the recession was developed and subjected to one of its first tests by Clark Warkurton, "The "Theory of Turung Points in Business Fluctuations," Quarterly Journal of Economics (November 1950), pp. 529-49. See also Milton Friedman, "A Theoretical Framework for Monetary Analysis," in Robert J. Gordon, ed., Milton Friedman's Monetary Framework (University of Chicago Press, 1974), pp. 1-62. Friedman provides a theory of nominal income in which velocity is procyclical due to deviations of monetary growth from the expected growth of nominal income (see especially pp. 38-48). He also indicates that this result is reinforced by deviations in money supply growth from growth in the demand for money (pp. $51-53$ ).
}

Table 2

Recent Growth Rates of the Money Stock (M) and Its Velocity

\begin{tabular}{|c|c|c|}
\hline Ouarter: & Money & Verody \\
\hline 1980011 & $169 \%$ & $62 \%$ \\
\hline & 98 & 92 \\
\hline 19811 & 50 & 14.8 \\
\hline II & 92 & 2.25 \\
\hline II & 31 & 98 \\
\hline W & 93 & 04 \\
\hline 1982 & 110 & $(1,12$ \\
\hline II & 3.3 & 3.6 \\
\hline 11 & 6.8 & 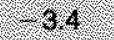 \\
\hline N & 137 & r. 99 \\
\hline
\end{tabular}

growth rates of $\mathrm{M} 1$ and velocity for the period from III/1980 to IV/1982. During quarters in which money growth accelerated, such as III/1980, II/1981, I/1982 and IV/1982, velocity growth was negative. Moreover, these periods followed unusually slow money growth, such as in the second half of 1981 and in II/1982. In periods when velocity growth slowed, including III/1980, II/1981, IV/1981, I/1982, III/1982 and IV/1982, the slowing was due in part to the contemporaneous acceleration in money growth and in part to the adverse reactions of GNP growth to past slowings in money growth.

\section{The Course of moentory Adjugment}

When sales growth slows in the late stage of a cyclical expansion or the early stage of a recession, firms may either fail to anticipate the decline, anticipate that the decline is more temporary than is the case, or simply choose to adjust production growth more slowly. In each event, firms would fail to reduce production as much as sales fell, thus accumulating undesired inventories. Since inventory investment, whether desired or not, is included in spending on final goods and services, GNP can be temporarily strong compared with desired spending, or GNP velocity can be raised relative to final sales (GNP less inventory investment) velocity.

Similarly, when sales expand in the late stages of a recession or early stages of recovery, firms may not anticipate the expansion, anticipate that it is only tem- 


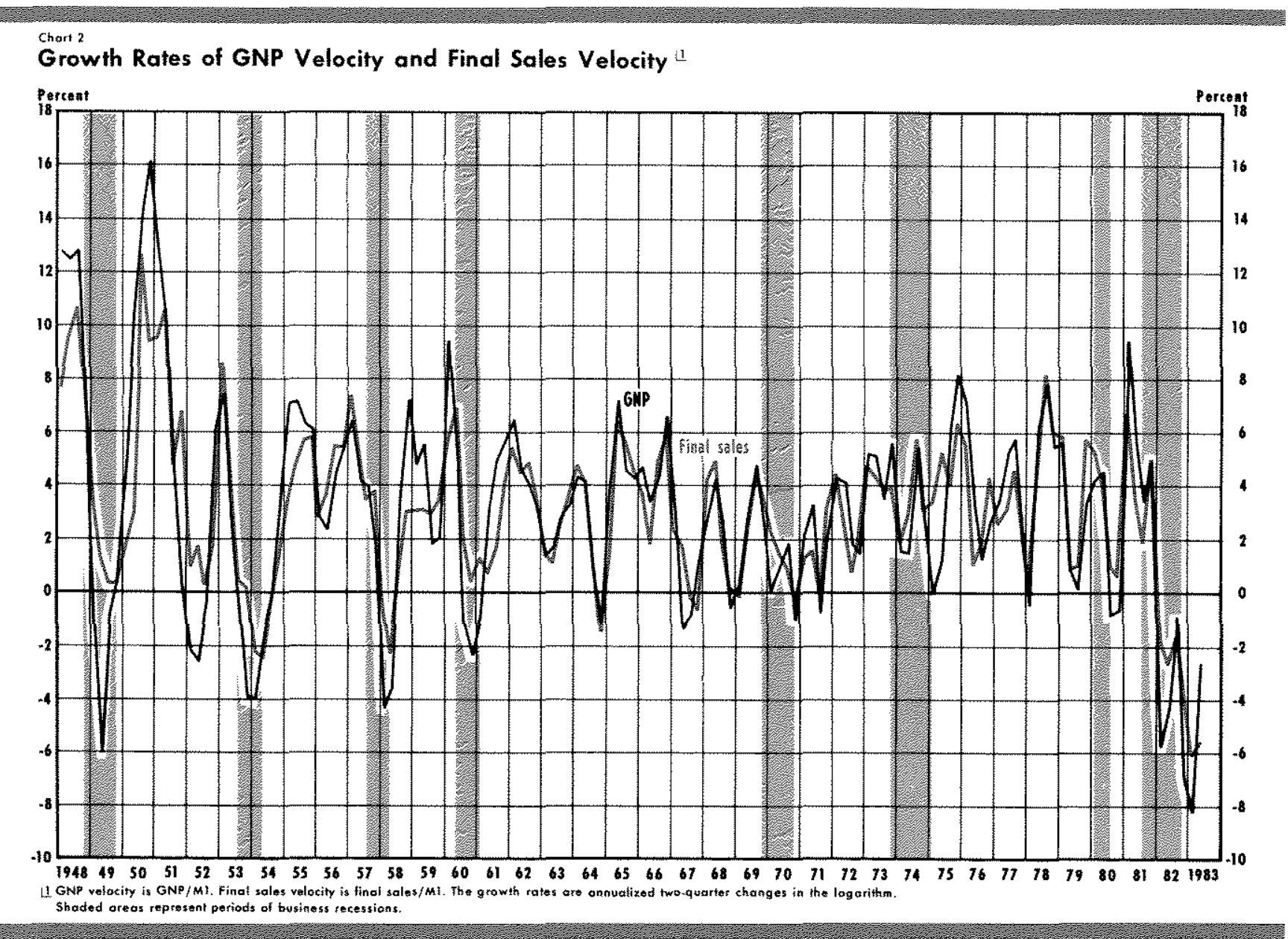

porary, or simply engage in production smoothing; thus, they initially will meet the sales increase out of inventory rather than stepped-up production. In this case, GNP will not keep pace with final sales, so that velocity measured relative to GNP will fall compared with velocity measured relative to final sales.

Chart 2 shows the growth rates of GNP velocity and final sales velocity since 1948 . Two-quarter periods are used to smooth the data somewhat. The average growth rates of the two series from I/1948 to $\mathrm{II} / \mathbf{1 9 8 3}$ are nearly identical ( 3.17 percent for GNP and 3.18 percent for final sales). The two measures of velocity growth are fairly similar except around the end of the shaded recession periods and the beginning of the recoveries. At these times, much wider swings occurred in GNP velocity due to inventory adjustments. ${ }^{14}$

\footnotetext{
${ }^{14}$ For a discussion of the importance of inventory movements before, during and after recessions, see John A. Tatom, "Inventory Investment in the Recent Recession and Recovery," this Review (April 1977), pp. 29. Also, Frank DeLeeuw, "Inventory Invest-
}

\section{Table 3}

Recent Developments in Real Inventory Investment, Output and Sales

\begin{tabular}{llll}
\hline \\
\hline
\end{tabular}

ment and Economic Instability," Survey of Current Business (December 1982), pp. 23 31, provides evidence of this greater volatility of production and demonstrates that the source of this "instability" is producers" lagged responses to changes in demand, especially in the adjustment of goods in process and material inventories. 


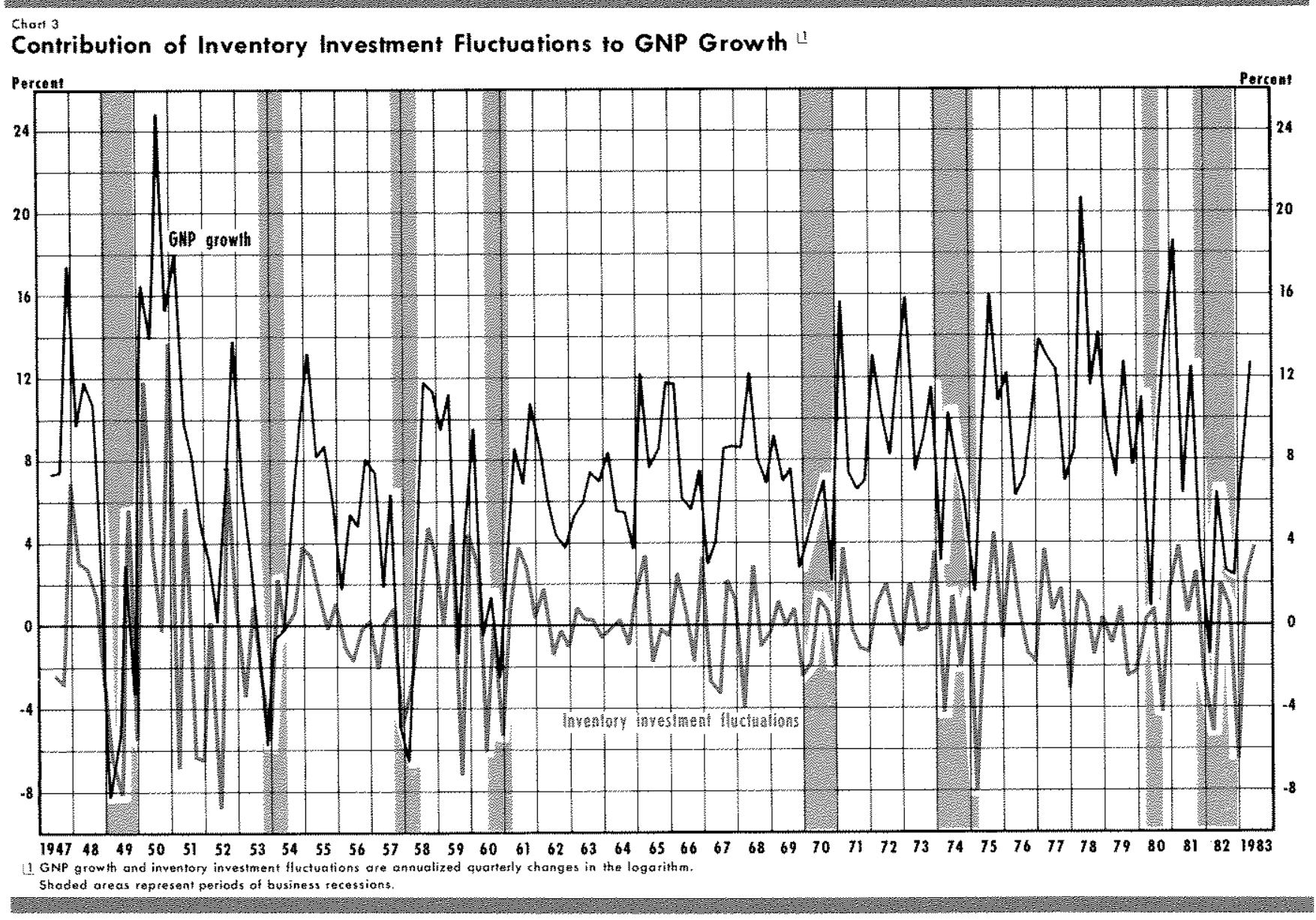

The recent divergence in the two measures of velocity growth is large, because of the sharp swings in inventory investment in the first and fourth quarters of 1982. Table 3 shows real inventory investment from the preceding peak to the end of 1982 , as well as real final sales and real GNP growth. The pace of inventory reductions in both the first and fourth quarters of 1982 ( $-\$ 10.2$ billion and $-\$ 22.7$ billion (1972 prices), respectively) are among the largest on record, with the latter exceeding the previous record of $-\$ 14.3$ billion in early 1975 . In both of these quarters, real final sales growth accelerated. Each of these sales accelerations was associated with a sharp acceleration to double-digit money growth (see table 2). In each case, the improvement in real sales was met out of inventory, indicating either that producers failed to anticipate the improvement, or that they were willing to treat it as an opportunity to eliminate undesired inventory, allowing production growth to rise more smoothly.

As noted above, GNP growth is more volatile than that of real final sales due to relatively large swings in inventory investment. On average, these swings should cancel out so that GNP growth matches final sales growth. One way to assess the contribution of inventory swings to GNP growth is to decompose GNP into the product of two components: $S$ and $(1+I / S)$, where $S$ is final sales and $I$ is the change in business inventories. The growth rate of nominal production (400 $\Delta \ln$ GNP) can be broken down into a component that arises from the growth of sales and a second component, the production growth which meets changes in the ratio of inventory investment to final sales $[400$ $\Delta \ln (1+\mathrm{I} / \mathrm{S})]$. Chart 3 shows this second component along with total GNP growth from 1947 to the second quarter of 1983.

On average, the growth rate of production matches that of final sales; the contribution of inventory swings $[400 \Delta \ln (1+\mathrm{I} / \mathrm{S})]$ is essentially zero $(-0.01$ percent $)$, though it ranges widely from about -8.8 percent to 13.5 percent in some quarters. The most pronounced effects are in recessions, when large negative effects are registered, and in the initial stages of recovery, when some of the large positive contributions of the end of inventory depletions are evident. Not surprisingly, the negative effects of inventory depletion in the 
first and fourth quarters of 1982 are among the largest negative effects shown in chart 3.

\section{WAS VEVOCIN GROWTH IN 1982

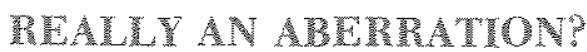

Weak or negative velocity growth is common during recessions because of ( 1 ) the influence of the transitory reduction in GNP with its smaller attendant reduction in the demand for money, (2) the pattern of money growth that usually gives rise to the recession, and (3) inventory adjustments that typically depress production relative to sales before or during the initial stage of a recovery.

To assess the cyclical nature of velocity, one must account for the strong trend in its growth rate, as well as several transitory or, perhaps, permanent effects arising from monetary and fiscal policy changes and other shocks. The direct cyclical component of velocity is captured by relating the level of velocity to the GNP gap, the percentage by which the nation's potential output exceeds its actual real GNP. ${ }^{15}$ An increase in the GNP gap reffects a decline in real income relative to potential output. Its effect on velocity indicates the operation of the income elasticity of money demand and captures, in part, the transitory effect of cyclical inventory movements on observed GNP.

It is well-known that current GNP growth depends on past as well as current monetary policy actions. Because the demand for goods and services responds with a lag, current GNP or velocity measures are subject to temporary movements arising from changes in money growth. Fiscal policy also can influence GNP; a fiscal measure, specifically the growth rate of highemployment federal expenditures, is included in the velocity equations below. ${ }^{16}$

\footnotetext{
${ }^{15}$ The GNP gap (G) is measured here by the difference in the logarithm of each series. This Bank's potential output series is used to measure the gap. It is explained in John A. Tatom, "Potential Output and the Recent Productivity Decline," this Review (January 1982), pp. 3-16. Changes in the CNP gap are highly correlated with other cyclical measures such as changes in measures of the capacity utilization rate or unemployment rate, so that they can often be used interchangeably. For example, the simple correlation coefficient between quarterly changes in the unemployment rate and the GNP gap is 0.70 over the period IIU/1948III/1981.

16The inclusion of lagged effects of monetary and fiscal policy is based on the Andersen-Jordan equation for GNP growth. See Keith M. Carlson, "A Monetary Analysis of the Administration's Budget and Economic Projections," this Retiew (May 1982), p. 14; and John A. Tatom, "Energy Prices and Short-hun Economic Performance," this Review (January 1981), pp. 3-17. The latter suggests the inclusion of some other factors that are discussed below. Lagged adjustment to money supply changes has also been
}

There are other factors that influence velocity, especially the opportunity cost of holding money instead of other assets. An increase in the cost of holding money reduces the demand for it and raises velocity, other things being equal. A major component of the cost of holding transaction balances is the rate of depreciation of the value of money, or the general rate of increase of prices. In addition, other assets can be held instead of money so that the real rate of return on alternative investments influences the decision to hold money. Given the expected inflation rate, movements in nominal interest rates reflect movements in real rates of return.

Velocity, then, is hypothesized to be a function of ( 1 ) current and past levels of the money stock (M) and high-employment expenditures (E); (2) inflation expectations, which, if expectations are unbiased, can be measured by changes in the rate of increase of the GNP deflator (P); (3) the rate of interest, in this instance, measured by the Aaa bond yield ( $r$ ); and (4) slack, measured by the GNP gap. Two other factors that affect GNP at least temporarily - strikes that temporarily affect production and spending $(S)$, measured by days lost due to strikes relative to the size of the civilian labor force, and movements in the relative price of energy $\left(p^{*}\right)$, measured by the producer price of fuel and related products and power deflated by the business sector implicit price deflator - are included.

\section{Estimating Velocity Growh}

To find the historical relationship of velocity growth to these factors, differences in logarithms are used to measure growth rates, in which case the variable is expressed with a dot above it. ${ }^{17}$ An estimate for veloc-

emphasized recently by Jack Carr and Michael R. Darby, "The Role of Money Supply Shocks in the Short-Run Dernand for Money, "Journal of Monetary Economics (September 1981), pp. 183-99. An earlier formulation and test of this hypothesis may be found in Leonall C. Andersen, "Observed Income Velocity of Money: A Misunderstood Issue in Monetary Policy," this Review (August 1975), pp. 8-19. The results here have the same properties and policy implications as the Andersen-Jordan equation.

${ }^{17}$ Arithmetically, veloeity growth in a quarter is the sum of the rates of increase of prices and real output, less the growth rate of money during the qlarter. Thus, the strong significance of these factors on the right-hand-side of equation 4 is not surprising. The use of accelerations in money and prices reduces biases arising from the arithmetic relationship. The fact that the coefficients on contemporaneous money, gap and inflation are significantly different from unity reinforces the explanatory power of the equation. The simple correlation coefficients between $\Delta \dot{M}, \Delta G$ and $\Delta \dot{P}$ are $(\Delta \dot{M}$, $\Delta G)-0.08,(\Delta \dot{M}, \Delta \dot{P})-0.03$, and $(\Delta G, \Delta \dot{P})-0.06$. Biases arising from the arithmetic relationship do not appear to be a substantial problem for the interpretation or quality of the regression reported in table 4. 


\section{Table 4}

\section{A Model of GNP Velocity Growth: III/1948- $11 / 1981$}
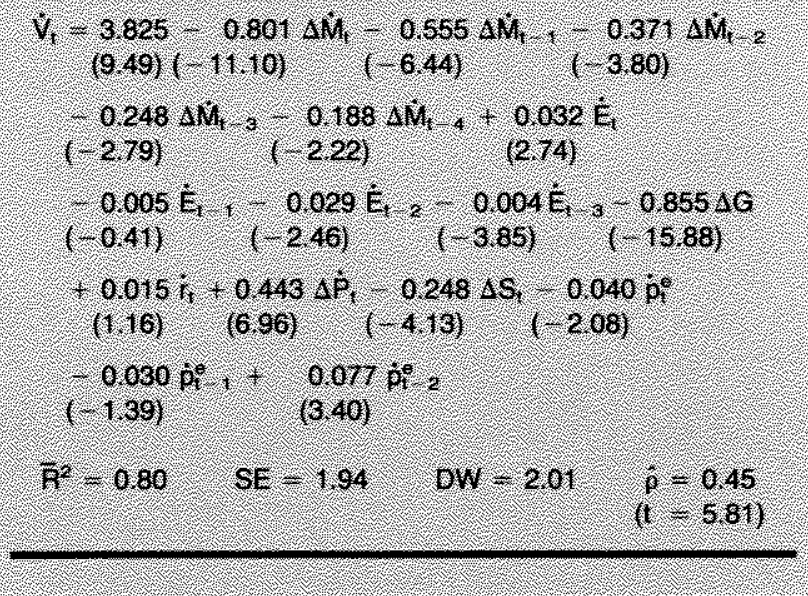

ity growth from III/1948 to III/1981 is given in table 4. ${ }^{18}$ The coefficients on the monetary growth terms indicate the cumulative sum of the effects of a rise in $\dot{M}$ on velocity growth. ${ }^{19}$ Thus, an acceleration in money growth in period $t$ by 1 percent initially reduces velocity growth in period $t$ by 0.8 percent; subsequently, velocity growth is depressed by less: 0.6 percent one quarter later, 0.4 percent two quarters later, then 0.2 percent, 0.2 percent and, five quarters later, not at all. If velocity had been growing at 3.8 percent, assuming all other influences remain the same, such a sustained increase in money growth would yield a series of velocity growth rates that fell and then rose: 3.0 percent, initially, then 3.2 percent, 3.4 percent, 3.5 percent,

\footnotetext{
${ }^{18}$ Long lag searches (up to 20 quarters for money and federal expenditure growth) were conducted for a sample period $/ 1955$ IIU/1981, because data limitations are too great for the period beginning in III/1948. The optimal lag structure, chosen by F. tests of sequential addition of individual lags and groups of lags, was the same as that used here.

${ }^{19}$ Suppose that $\dot{V}_{t}=\beta_{0} \dot{M}_{t}+\beta_{1} \dot{M}_{t-1}+\ldots+\beta_{n} \dot{M}_{t}{ }_{n}$; then $\dot{V}_{t}=$ $\beta_{0} \Delta M_{t}+\left(\beta_{0}+\beta_{1}\right) \Delta \dot{M}_{t-1}+\ldots+\left(\sum_{i=0}^{n-1} \beta_{i}\right) \Delta \dot{M}_{t-n-1}+$ $\left(\sum_{i=0}^{n} \beta_{i}\right) \dot{M}_{t-n}$. If the permanent effect of a rise in $\dot{M}$ on $\dot{V}$ is zero, the last term vanishes. In the equation in table 4 , the absence of a permanent effect can be tested by adding the money growth rate lagged five quarters to the equation. When this is done, its coefficient $(-0.103)$ is not significantly different from zero $(t=-0.78)$. Consequently, this permanent effect is constrained to zero in table 4 and for the examination of the recent experience. The coefficients on the $\Delta M$ terms are estimated to lie along a second-degree polynomial without endpoint constraints. The Fstatistic for the polynomial restriction is $F_{2116}=2.47$, so that the polynomial restrictions cannot be rejected.
}

and 3.5 percent, before returning to 3.8 percent five quarters later. There is no permanent effect of money growth on velocity growth, only transitory effects that disappear after five quarters.

The effect of the GNP gap on velocity is highly significant: each 1 percent increase in the gap reduces velocity by almost 0.9 percent. An increase in highemployment federal expenditures initially raises velocity, then reduces it. Energy price increases initially reduce velocity, then raise it, other factors remaining the same. ${ }^{20}$ An increase in inflation significantly and permanently raises the level of velocity. The interest rate is not significant at conventional levels, but is included since it has the expected sign and a $t$-statistic that is greater than one. ${ }^{21}$ Finally, strikes temporarily reduce velocity..$^{22}$

\section{Velocity Growth in the Recent Recession}

When velocity growth is simulated for the $1981-82$ recession, the equation tracks the actual developments quite well (see table 5). Despite the sharp reductions in velocity in the first and fourth quarters of 1982, unusual errors do not result. While undue attention to every wiggle in velocity growth is clearly to be avoided, it is worth noting that the record movements in inventories during these two quarters and their

\footnotetext{
${ }^{20}$ The sum of the federal expenditure effects on velocity is -0.047 and it is not significantly different from zero $(t=1.68)$. The sum of the energy price effects, 0.007 , is also insignificant $(t=0.24)$. High-employment expenditures and energy prices have no permanent effect on velocity.

${ }^{21}$ When a short-term interest rate, the 4- to 6-month commercial paper rate, is used instead of the Aaa bond yield its insignificant $(t=0.78)$ coefficient is 0.003 . Otherwise, the equation estimates are virtually identical. Allowing the interest elasticity of velocity to be a positive function of the interest rate, by using $\Delta r$ rather than $\Delta$ in $r$, resulted in a higher standard error of estimate for both long- and short-term rates. For both rates, moreover, the coef ficient reverses sign and the t-statistic falls below one-half. The small t-statistic reported for $r$ in table 4 does not result from collinearity with changes in the inflation rate; the correlation coefficient of these two variables is virtually zero $(-0.007)$.

${ }^{22}$ The model shown in table 4 can also be ased successfully for final sales velocity growth, except that strikes, interest rates, and contemporary energy price changes do not affect it significantly. The model has the same properties; money growth, high-employment expenditure growth, and changes in the relative price of energy do not have significant permanent impacts on final sales velocity. The adjusted $\overline{\mathrm{R}}^{2}$ of the final sales velocity growth rate is 0.46 over the period used in table 4 . This equation is stable across the IV/1973 and $111 / 198 \mathrm{I}$ breakpoints at a 95 percent confidence level.

The gap coefficient in the final sales equation is much smaller $(-0.44)$, indicating that the cyclical component of GNP velocity is capturing some of the inventory adjastment. A decomposition shows that money growth accounts for most of the sharp negative
} swings of GNP velocity growth, however. 


\section{Table 5}

\section{Simulating GNP Velocity Growth in the Recent Recession'}

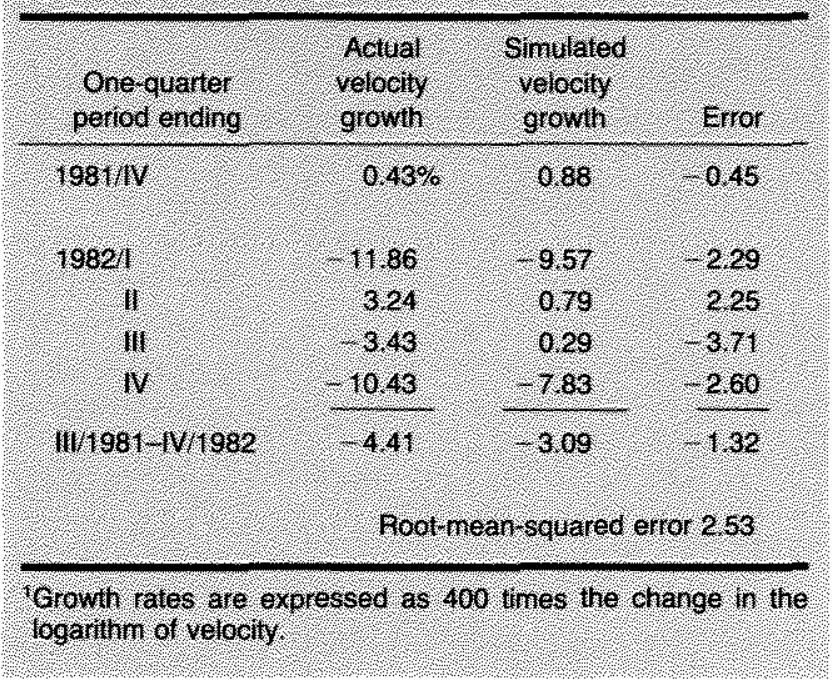

impact on production and velocity are captured surprisingly well. The mean error for the recession period (1.32 percent) and the root-mean-squared error ( 2.53 percent) are not at odds with the quality of the errors characterizing the prior behavior of velocity growth, indicated by the equation's standard error of 1.94 percent. ${ }^{23}$

When the equation in table 4 is re-estimated for the longer period to IV/1982, the F-statistic that is used to test for a structural change between the earlier period and the latest five recession quarters is $F_{5,123}=1.55$, which is not significant at a 95 percent confidence level. This F-test and the evidence in table 5 indicate that the historically weak performance of velocity in the recent recession is not unusual; that is, it has resulted from the normal working of factors that tend to depress GNP velocity in recessions, not from a major breakdown of past relationships. ${ }^{24}$

The coefficients in the velocity growth equation can be used to decompose the simulated growth rates into the direct contribution of each variable during the

\footnotetext{
${ }^{23}$ The equation in table 4 can be used to generate simulations for velocity growth in earlier recessions (see table 1 ) on a comparable basis. When this is done, the direction of the velocity movement in each of the seven previous recessions is accurately simulated: the mean absolute error for these seven recessions is 1,07 percent.

${ }^{2}$ The equation in table 4 is stable according to a Chow test. Also, when the sample period is broken at the fourth quarter of 1973 the $F$-statistic is $F_{15,103}=1.45$, which is not significant at a 5 percent significance level.
}

Table 6

\section{Factors Accounting for Velocity Growth: 11/1981-IV/19821}

\begin{tabular}{|c|c|}
\hline 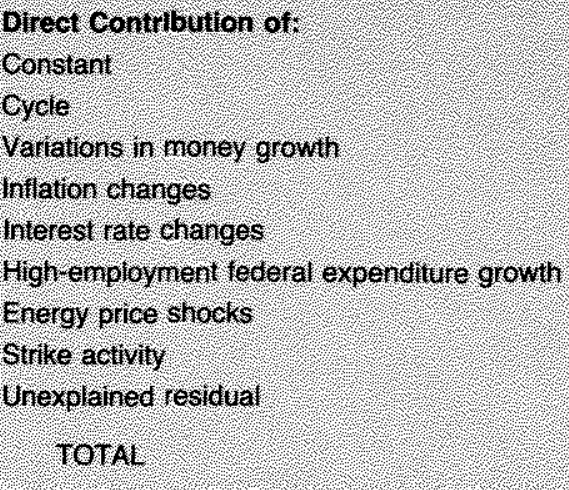 & 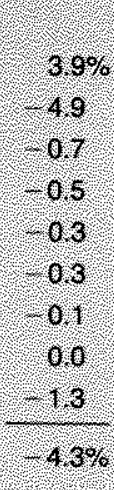 \\
\hline
\end{tabular}

recent recession. ${ }^{25}$ The results for the recent recession period appear in table 6 . The primary factor accounting for the decline was the normal cyclical response to the transitory decline in income associated with the recession; this effect, measured by the change in the GNP gap and indicated in the table as the "cycle" influence, was -4.9 percent. The second major factor was the transitory effect arising from variations in money growth before and during the recession. Since the primary determinant of the decline in real output or the size of the GNP gap is the pattern of past monetary growth, the lion's share of the recent behavior of velocity is directly or indirectly attributable to the volatile path of monetary growth.

Other factors played minor roles. In particular, declining inflation and declining interest rates each con-

\footnotetext{
${ }^{25}$ The major controversy addressed here is the velocity declime in the recent recession, especially in 1982 . In the first quarter of 1983 , velocity fell at a 5.75 percent compounded annual rate. The decline, while substantially smaller in size than those in the first and fourth quarters of 1982, is noteworthy for its size in the absence of a major swing in the contribution of inventory liquidations. Indeed, while real inventory investment remained negative, $\$-15.4$ billion ( 1972 prices), the contribution of inventory investment to GNP growth was positive, +2.3 percentage points, since the pace of liquidation slowed. More important, when the velocity model is used to make a one-quarter-ahead forecast from IV/1982, the predicted velocity growth rate is -0.9 percent. Thus, the error in $1 / 1983$ is significantly larger (2.5 times larger) than the standard error of the estimating equation. None of the F-test results or conclusions about the five-quarter simalation experiment in table 5 are altered if the first quarter of the recovery is
} included, however. 
tributed 0.5 percentage points or less to the decline. Nonetheless, these other factors amplified the decline somewhat. ${ }^{26}$

\section{CONGLUSION}

The velocity of money fell sharply in the recent recession, suggesting to some observers at least that the relationship of the money stock to total spending had broken down. Indeed, many observers went on to posit new hypotheses concerning the reasons for the velocity decline such as financial innovations, foreigners' attractions to dollar assets, or unusually strong reactions to the slowing of the U.S. inflation rate or interest rates. Upon closer scrutiny, however, the timing and magnitude of these developments do not match up well with velocity developments in the recent past.

The velocity decline does appear, superficially, to represent a major break from past experience and, therefore, to be a source of concern for policymakers. After all, in 1982 velocity fell at a 2.3 percent rate (year over year) after rising at a 3.2 percent average rate over the previous 22 years, suggesting a shortfall of 5.5 percentage points. On a quarter-to-quarter basis, the decline in velocity during the recent recession was even larger.

It is not unusual, however, for velocity to decline in a recession. It is, in fact, quite typical. Short-term movements in velocity reflect diverse reactions of the economy to monetary policy actions. In a recession, all of these reactions generally contribute to a temporary decline in velocity. Given the length and severity of the recent recession, where the severity is measured by the unemployment rate or the gap between the nation's potential and actual real GNP, it is not surprising that velocity registered the largest decline in postWorld War II recessions.

\footnotetext{
${ }^{26}$ Interestingly, compared with the previous sever postwar recessions, the cydical component was not unusually large in the recent recession. The cyclical contribution (compounded annual rate from cycle peak to trough) in the seven recessions from $1948-49$ to 1980 is estimated to be -5.4 percent, -5.2 percent, -5.1 percent, -2.9 percent, -3.0 percent, -4.7 percent and -5.0 percent, respectively. Four of the previous seven effects exceed the recent cyclical effect.
}

A detailed development of the standard hypotheses concerning velocity behavior, including the transitory influences of monetary growth, fiscal policy, and energy price shocks on observed spending and velocity, suggests an empirical formulation that accounts well for velocity behavior in the post-World War II era. More important, simulations of this historical experience for the recent recession indicate that there were no significant breakdowns in the relationship of the factors accounting for velocity behavior.

In a previous study of velocity movements, Andersen concluded that "the use of observed changes in velocity growth, by themselves, in conducting monetary policy is often misleading and potentially dangerous." ${ }^{27}$ This conclusion is perhaps most important surrounding recessions and the early stages of recovery when velocity movements are so strongly influenced by the temporary effects of past monetary actions.

Monetary growth tends to be most variable around a period of recession, especially when a sizable decline initially sets off the recession itself. Such a variation in money growth creates temporary movements in velocity; not only is the supply of money in flux, but real output is as well, as the demand for money adjusts to the money supply variation. Variations in real output and velocity are further enlarged temporarily by inventory adjustments.

In the recent recession, these processes were magnified by the degree and extent of monetary stringency during some periods prior to the recession. As a result, the normal cyclical movement of money demand was large, and swings in inventory investment further distorted, temporarily, the movements of velocity. Other factors, including the temporary decline in inflation and movements in interest rates, federal expenditures and energy prices all worked in the same direction, reducing velocity in the recent recession. Thus, the extent of the decline in velocity in the recent recession was not unusual, nor did it represent an atypical shift with important, but unknown, implications for policymaking.

${ }^{2 *}$ Andersen, "Observed Income Velocity of Money," p. 19. 